\section{Tussock jumping...}

\author{
Peter Ward \\ Chief Executive, BDA
}

Send your comments to the

Editor-in-Chief,

British Dental Journal

64 Wimpole Street,

London

W1G 8YS

Email bdj@bda.org
The recent court victory of Birmingham orthodontist Eddie Crouch was an important milestone, effectively preventing a primary care trust (PCT) from inserting its own arbitrary terms into a PDS agreement. The substance of the case was that in spite of a whole battery of references to the contrary, the PCT had decided at the contract drafting stage to insert a clause that would permit them to terminate the contract (which was supposed to be protected for five years), at any time and for any reason, on one month's notice. It is therefore clear why the BDA supported Dr Crouch's case so vigorously. Had this unilateral imposition been endorsed by the courts it would have left all NHS contractors in England and possibly Wales open to similar threats and what little predictability remains within the GDS and PDS would have been shot asunder.

And so, in support of Dr Crouch's argument, the BDA intervened in the case as an interested party. We made very serious consideration of the risks and benefits (which were legally complex) and instructed senior legal counsel to draft what proved to be very powerful supporting arguments in support of Dr Crouch. As our duty is to use the Association's funds wisely we had to determine the impact and likely success of the case. Given the significance of the subject matter and the possible effects upon thousands of members we took the view this was a cause worth fighting. There was another head of claim upon which we took equally senior advice, and were advised that its chances of success were very small. We passed that advice on to Dr Crouch and we decided not to pursue an intervention on that point.

The challenge of the PCT's unilateral variation should have been upheld by the NHSLA and the judge held that the PCT had acted contrary to the regulations and had no right to vary contracts in the way that they had tried. At the time of writing, we have not yet heard whether the PCT is to appeal.

The judge was unambiguous in his criticism of the new regulations. He described them as of inordinate length and pitied the poor dentists who have to plough through all the verbiage. Perhaps most tellingly he described the process of trying to follow the regulations as like 'going through a marsh, trying to leap from tussock to tussock'... This commentary was very interesting coming from an intelligent, informed and impartial bystander. Consequently, the judge confirmed all of our worst criticisms of this hastily written and ill-conceived set of regulations. Effectively, despite the repeated affirmations of
Department of Health (DH) officials, an independent arbiter has agreed with the profession and confirmed that the underpinning rules of this contract are fundamentally flawed. Significantly, these comments were peripheral to the case, relating to the generality of the regulations. Of his own volition, the judge chose to express his deep concerns about the contract and those who suffer its consequences.

\section{IF ALL ELSE FAILS WRITE THE INSTRUCTIONS}

In similar vein, at a session of the House of Commons Health Select Committee's inquiry into the new dental contract, the Chair opened his questioning of the DH by pointing out that the Committee had received evidence from a variety of sources and that all bar a very small number (principally the DH itself) said that there were serious problems with the new arrangements. He asked how these views could be so different. We await the committee's findings, but the proceedings revealed the absence of long term planning and the lack of a clear current focus. Parliamentarians expressed grave concern that having announced funds to SHAs to augment areas of shortage there was no clear formula or mechanism for their allocation. The DH explained it would be working on a formula and a five-year analysis of where NHS dentistry was heading. It is alarming to think that these things were not already developed. It's really a case of 'if all else fails write the instructions!'

However, being proved right doesn't really help. Yes the regulations are poorly drafted and ill-thought out; there is no coherent long term plan - and never was. Announcements of 'new money' seem to be more about the announcement than the substance.

Despite it being an uninspiring time the BDA continues to work hard to support its members by providing more help locally and looking at the key relationships between commissioners and dentists. Thousands of you have been in touch personally for individual advice. We'll also continue to explain to the DH what should be done to alleviate the worst problems created by the changes and come up with positive, practical ideas.

Now that all the cynical suppositions have been proved true, colleagues must be absolutely clear that their futures are entirely in their own hands. It's time to look to the interests of our own patients, practices and ourselves.

DOI: $10.1038 /$ sj.bdj.2008.267 